\title{
Employee Turnover and Organizational Performance: a Study of the
} Brazilian Retail Sector

\author{
Luciana Carvalho de Mesquita Ferreira ${ }^{\dagger}$ \\ Insper \\ Ciro Barbosa de Aquino Almeida ${ }^{\Omega}$ \\ Insper
}

\begin{abstract}
This study investigates the relationship between employee turnover and performance in retailing. To achieve this aim, we used data from a single company with several comparable branches and tested whether stores with lower employee turnover have better financial and organizational results (sales and workplace accidents, respectively). This study also analyzes whether Human resources practices, such as rewards, recognition and training, affect employee turnover. The empirical results indicate a strong relationship between employee turnover and sales, supporting results from previous studies. However, the additional relationships were not confirmed. The results do not rule out some hypotheses about the relationship between employee turnover and labor accidents, and further suggest that human resources management practices may increase employee turnover, depending on their motivation and strategic alignment.
\end{abstract}

Keywords: Employee turnover. Performance. Retail. Brazil.

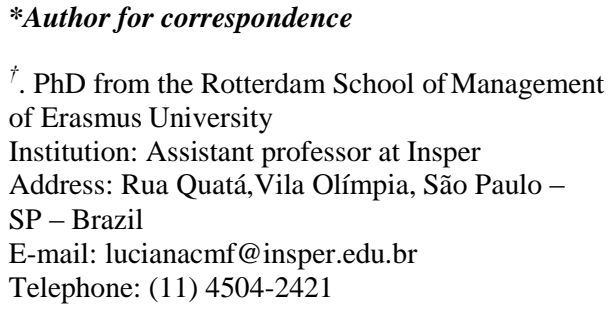

Note from the Editor: This article was accepted by Emerson Mainardes.

\footnotetext{
${ }^{\Omega}$ Professional Master's Degree in Business

Administration from Insper

Institution: Manager of the Human Resources

Department of Saint Gobain

Address: Rua Sena Madureira,São Paulo - SP - Brazil

E-mail: ciro.almeida@saint-gobain.com

Telephone: (11) 98173-9423
} 


\section{INTRODUCTION}

he importance of maintaining qualified employees for the success of organizations is not a new theme. The theory of human capital, developed by Becker (1994), indicated the positive impact of education on the productive capacity of workers and companies. Becker (1994) further suggested that education, obtained formally in school by on-the-job practice, has positive effects on the economy at the individual and aggregate level.

What is relatively recent is the increase in interdependence of various social actors and society as a whole, the intensification of interactions in the workplace, and the increased dynamism of the organizational environment. These characteristics are the result of the change in profile of the global economy, which has shifted from a manufacturing and industrial structure to an economy based on services and knowledge (GRANT; PARKER, 2009). This means that the social relationships and self-initiative of employees regarding anticipation and implementation of changes in the way work is done are gaining more importance. In this new context, losing employees tends to be even more prejudicial to organizations.

More specifically in the Brazilian context, companies are facing rising difficulties in retaining their employees. Although the past two decades have been marked by steady growth of the economy and the number of jobs, both favored by the end of high inflation in mid1994, this period is also characterized by higher employee turnover. According to the Ministry of Labor and Employment (MTE), 19 million jobs were created in the formal sector between 2000 and 2010. However, roughly two-thirds of these jobs ended before 12 months had passed (MTE 2010).

Among the various sectors of the Brazilian economy, retailing is one of those that generates most concern regarding the possibility of underutilization of capacity, both with respect to its size and employee turnover rate. According to the MTE, in 2010 the sector accounted for $19 \%$ of the total number of layoffs/resignations, or about 8.4 million jobs. Besides this, from 2007 to 2009, the turnover rate in retailing was over $40 \%$ a year.

In light of this context, this study investigates the relationship between worker turnover and organizational performance in the retail sector. For this purpose, we test whether organizations with lower employee turnover tend to obtain better results, both in economic terms (sales volume) and organizational terms (workplace accidents). Besides this primary 
objective, we also test how some personnel management practices, more specifically recognition and training actions, affect the turnover rate.

From a management perspective, this study sheds light on the effects of worker turnover on business results, besides suggesting that policies to retain employees should be prioritized by human resources professionals. Furthermore, it has potential to stimulate research in the human resources area to find practices and policies with a direct or indirect impact on companies' performance.

The article is structured as follows: the first section presents the context of the problem and its relevance; the second discusses the main theoretical perspectives about the effects of turnover on organizational performance, and also develops the hypotheses tested; the third section presents the methodological approach to respond to the research questions; the fourth discusses the results found; and the last section summarizes our main conclusions and indicates some avenues for future research.

\section{THE CONTEXT OF THE STUDY: EMPLOYEE TURNOVER IN BRAZILIAN RETAILING}

The improved performance of the Brazilian economy in recent years has led to steady growth in the number of jobs in the labor market. According to information from the Brazilian Central Bank, the country's gross domestic product (GDP) grew by an average yearly rate of $4.2 \%$ between 2005 and 2010, against an average of 1.1\% in the United States and $1.0 \%$ in the Euro Zone during the same period. Figures from the MTE contained in the report "Characteristics of Formal Employment" of the Annual List of Social Information (RAIS) for 2010 indicate that in the preceding decade more than 19 million formal jobs were generated by the Brazilian economy, raising the total from 25 million at the start of 2000 to 44 million in December 2010.

The strengthening of the job market is a reflection of the development of the nation's economy. However, in analyzing the average length of labor contracts it is possible to note that in the same time frame there was a reduction in this average. Information from the study "Contractual Movement in the Formal Labor Market and Turnover in Brazil", published by the MTE (2010), which contains data through the end of 2009, indicates that nearly $66 \%$ of the employment relationships in the country ended before the passage of one year and $79 \%$ ended within two years.

That study on worker turnover indicates the sectors of the economy with the highest annual rates. The leaders in the ranking are: civil construction (86.2\%), agriculture $(74.4 \%)$ 
and commerce (41.6\%). Although the construction and agriculture sectors hold the first two places, these sectors have relatively low weights in the total number of jobs (respectively $5.7 \%$ and $3.2 \%$ in 2010, according to data from the RAIS). Besides this, civil construction relies heavily on temporary labor contracts, as does agriculture due to the seasonal character of production. Therefore, commerce, which in 2010 accounted for $19 \%$ of the formal jobs in the country, is the sector where the problem of employee turnover is most pronounced.

Data from the study on remuneration called "Club Survey Retail Sector", organized by the Hay Group (2011), also indicates this pattern in the sector. The survey, which involved participation of the 30 largest retailing companies in Brazil, with 475 thousand employees, showed growth of turnover. Between the start of 2010 and start of 2011, the turnover rate was $58 \%$. In other words, in just one year nearly three-fifths of the workforce of these companies was renewed.

This context demonstrates the relevance of the focus of this study. In the next section we report the results of previous investigations of worker turnover, separated into two subtopics: (i) the relationship between employee turnover and organizational results; and (ii) the relationship between human resources practices and turnover.

\subsection{EMPLOYEE TURNOVER AND ORGANIZATIONAL RESULTS}

The academic literature started to address the subject of employee turnover more intensely in the 1970s. Since then, various studies have been carried out, particularly investigating the relationship between this parameter and companies' results.

One of the first studies to discuss the influence of the departure of employees on the performance of firms was Pencavel (1972). The author developed a model that contemplates the aspiration of the organization in having a determined turnover rate, considering a management trade-off between maintaining operations with a high turnover rate but lower wages or a low turnover rate with higher wages. After testing his model in manufacturing industries in the United States, he found that the optimal strategy depended on the type of employees leaving. In this case, the higher the qualification of the workers, the greater were the costs to the employer, and that overall high turnover implied negative impacts on the companies.

Recently, Shaw, Gupta and Delery (2005) called attention to a previous study by Price (1977). According to the authors, the relation between turnover and results is not linear because the negative effects are attenuated as the turnover rate increases. In other words, 
turnover is more harmful at the start of the curve and less so at the end of the curve, when the indicators are higher. They explained this hypothesis by arguing that when turnover is low, when an employee leaves, this person is likely to have good qualification and will be replaced by someone who will not have the same experience in that job position, causing the overall knowledge of the firm to decline. On the other hand, when the turnover rate is high, the replacement of a worker does not represent such a great loss of knowledge for the firm, and the new employee can more quickly reach the same level of qualification as the predecessor.

Dalton and Todor (1979) questioned whether the relationship between turnover and company performance is always negative. They took a positive focus, discussing the organizational, economic, social and psychological effects. They recognized that high rotation levels can have a negative impact on firms, but they also found evidence of positive aspects of this relationship, when the turnover rate is controlled at a low level.

From the organizational standpoint, Dalton and Todor (1979) stated that turnover of workers improves cooperation among the areas and people of the company, stimulates an environment of innovation, and as a consequence can bring long-term gains. From this perspective, extremely low turnover rates can cause stagnation and the development of "closed minds", not receptive to new ideas and learning. Furthermore, from a macroeconomic perspective, the authors argued that mobility of people (measured by the employee turnover rate) improves a country's production, given that people can take their knowledge to other businesses and places. Socially, the positive aspects of turnover are connected to the evolution of individuals, who through greater mobility can advance in their careers more quickly, besides finding places where they can better apply their potential, resulting in less social inequality. Finally, from the psychological standpoint, efforts to prevent employees under stress or pressure from leaving can increase absenteeism, apathy, sabotage and other undesirable behaviors. However, Dalton and Todor (1979) stressed that these benefits can only be generated when the turnover rates are not too high.

Abelson and Baysinger (1984) presented similar argumentation as Dalton and Todor (1979). According to the authors, all companies have employees they want to retain (essentially those with high performance) and others that are less important, whose leaving will only cause a slight organizational rearrangement. When losing high-performing employees, companies face dysfunctional turnover, while in the case of other employees, this turnover is functional. The study of Abelson and Baysinger (1984) is also important because the authors suggested that the optimal turnover rate depends on various factors, such as 
distinct competitive environments (e.g., monopolistic or oligopolistic competition), types of organizations (e.g., distinct targets, different technologies, etc.) and labor attributes (e.g., different levels of required knowledge depending on the function or business). In other words, turnover is a multilevel phenomenon and depends on the characteristics of the company.

In the next decade, Alexander et al. (1994) tested the hypothesis that employee turnover reduces organizational efficiency, specifically studying hospitals. Based on a survey of 333 hospitals in the United States, the authors concluded that the relationship between turnover and organizational inefficiency (in terms of operating costs and labor costs) is linear and positive. More recently, other authors have tested this same hypothesis in different settings. McElroy, Morrow and Rude (2001) investigated the relationship between turnover and profits from loans given by bank branches. Kacmar et al. (2006) tested the relationship between turnover and sales of a fast food restaurant chain in the United States. In turn, Siebert and Zubanov (2009) examined the relationship between turnover of sales clerks and labor productivity in 325 stores of a retail clothing company in the United Kingdom between 1995 and 1999. In general, the results of these studies indicate that the relationship between employee turnover and organizational results is predominantly negative.

\subsection{HUMAN RESOURCES MANAGEMENT PRACTICES AND EMPLOYEE TURNOVER}

Various studies since the 1990s have examined the relationship between human resources practices and worker turnover (ARTHUR, 1994; HUSELID, 1995; BATT, 2002; SHAW et al., 2009; BATT; COLVIN, 2011). In them, the operationalization of "human resources management practices" involves policies for incentives, investment in training and recruitment/selection processes, among others.

According to Arthur (1994), the relationship between turnover and organizational results (measured by worker performance) varies according to the investments made in human resources management. Those investments are connected to practices to develop people (training actions, for example) and also to practices focused on retaining employees (such as wages and benefits). The author tested his model in steel minimills and concluded that the greater the allocation of investments for human resources practices, the higher will be the retention of workers and their impact on labor force performance.

Huselid (1995) carried out a study similar to that of Arthur (1994), analyzing human resources practices from three standpoints: strategy; labor productivity and financial results; and degree of complementarity between practices and the alignment with competitive 
strategy. He gathered data on about three thousand firms in various segments. One of the results was that human resources practices, when they have complementarity or synergy, have economic and statistical relevance both in reducing turnover and in boosting labor productivity.

Batt (2002) studied the relationship between human resources practices and employee turnover in the service sector, particularly in call center companies. She identified lower turnover rates and higher sales growth in organizations that emphasize high skills, employee participation in decision making and incentives such as good wages and job security.

Shaw et al. (2009) investigated what types of human resources practices are most effective in reducing turnover in two distinct environments: trucking companies and supermarkets. They grouped the practices into two categories: incentive and investment practices (involving policies on wages and benefits, job security and procedural justice); and expectation-enhancement practices (involving monitoring of activities, performance assessment and variable compensation tied to performance). Shaw et al. (2009) compared these two types of practices with the classification of turnover proposed by Abelson and Baysinger (1984) and found that incentive and investment practices were negatively related both to functional and dysfunctional employee turnover rates. In turn, expectationenhancement practices were negatively related to dysfunctional turnover rates and positively related to functional turnover rates. Therefore, the findings of Shaw et al. (2009) supported earlier findings, including making an important contribution by indicating that good human resources practices can enhance employee retention, particularly the functional type.

\subsection{HYPOTHESES: TURNOVER, PERFORMANCE AND HUMAN RESOURCES PRACTICES}

The context of the study discussed previously and the literature review suggest that employee turnover has a negative impact on business results. In the academic literature, the "results" variable is operationalized by the economic approach (in terms of costs, sales or profits), as employed by Pencavel (1972), Dalton and Todor (1979), Alexander et al. (1994) and McElroy, Morrow and Rude (2001), and by means of the organizational approach (in terms of level of knowledge of the firm or investments in human resources management), as used by Dalton and Todor (1979), Arthur (1994) and Shaw, Gupta and Delery (2005).

Here we consider both of these approaches: economic and organizational. For this purpose, we apply indicators that can contribute to the analysis from a methodological standpoint and that at the same time are relevant to the management of the focal company. 
Therefore, we analyze the results from the perspective of sales (economic approach) and workplace accidents (organizational approach), based on the arguments put forward by the various authors discussed previously, according to the following two hypotheses:

Hypothesis 1a: The higher employee turnover is, the lower will be the store's sales.

Hypothesis 1b: The higher employee turnover is, the higher will be the store's workplace accident indices.

Some authors, among them Abelson and Baysinger (1984), Williams (1999) and Glebbeek and Bax (2004), have argued that the sensitivity of organizations to worker turnover should be analyzed considering specific features of the organizational context. Therefore, when assessing the effects of turnover on organizational performance, it is possible to contemplate aspects related to the company and/or the economic sector. A possible organizational performance indicator is absenteeism, as suggested by Glebbeek and Bax (2004). However, according to these same authors, employee absenteeism is a performance variable that captures other effects besides those related to the company and/or sector. Therefore, we opted for workplace accidents as an indicator of organizational performance because it better permits capturing a possible relationship between the organizational environment and performance (WILLIAMS, 1999).

Besides this, as mentioned previously, the methodological option for an organizational approach is also based on the relevance of determined management dimensions, which vary according to the company or industry analyzed. As will be presented in the Data and Methods section, our focal company's sensitivity in relation to turnover can be better assessed by the rate of workplace accidents since there is substantial movement of heavy materials at the stores in question, increasing the risk of accidents in this context.

The literature review also indicates that the variables commonly applied to operationalize human resources practices are training and wage/benefit policies. In line with this and considering the high turnover rate of Brazilian workers (implying greater efforts to attract people), we propose a second set of hypotheses to analyze relevant antecedents of turnover:

Hypothesis 2a: The greater the frequency of promotions and pay increases, the lower the store's employee turnover will be.

Hypothesis 2b: The higher the number of training hours per employee, the lower the store's employee turnover will be. 


\section{DATA AND METHODS}

In this section we present our empirical strategy. One of us had access to management information of a representative company in the retail sector. Hence, the data used in this study were obtained and compiled from management reports and the information system of the focal company.

\subsection{SAMPLE}

To test the hypotheses, we selected a sample composed of data on various branches of the same company (Focal Firm), permitting better comparability between organizations (in this case, branch stores). This type of approach has been widely used in studies of employee turnover, mainly after publication of the article by Glebbeek and Bax (2004). Among the advantages of this approach of studying a single company with many branches is less need for control variables (such as management practices, nature of operations, specific economic conditions or a segment or region, etc.).

Siebert and Zubanov (2009) also applied this approach in their article and mentioned the additional benefit of ease of repeating the method in other companies that have comparable branches or subsidiaries. Other examples of this methodological option are Kacmar et al. (2006), who performed a study with data on Burger King restaurants; Morrow and McElroy (2007), whose examined bank branches; and Shaw et al. (2005), who also applied the method to a chain of restaurants.

The Focal Firm operates a chain of stores selling construction materials. Data from the Brazilian Institute of Geography and Statistics (IBGE) show that retail sale of construction materials accounts for some $0.84 \%$ of the country's GDP and $13 \%$ of national retail sales. According the study called "Annual Commercial Survey 2009" (IBGE, 2011), in 2009 this segment contributed just over $\mathrm{R} \$ 17.2$ billion toward GDP, obtained operating revenue of $\mathrm{R} \$$ 63.6 billion, through 126,192 companies and 130,371 local sales outlets, and employed over 772,500 people.

In December 2009, the Focal Firm had 3,184 registered employees, making it one of just 24 Brazilian retail companies in general (not only in construction materials) with a headcount greater than 1,000 that year. With gross revenue of $\mathrm{R} \$ 1.34$ billion in 2009 , the Focal Firm had a market share of approximately $2.1 \%$. Although this market share may at first glance appear low, this sector is marked by a high degree of dispersion, largely composed of micro-enterprises. According to the IBGE, of the 126,192 companies in the market in 2009, only 4,040 had 20 or more registered employees. There are very few large players in this 
market, and only four of them, including the Focal Firm, operate in more than one state. Table 1 summarizes the macro data on the market and the representation of the Focal Firm in each of the aspects listed.

Table 1 - Data on the Focal Firm in Relation to the Market (Retail Sales of Construction Materials), for 2009

\begin{tabular}{lcr}
\hline & Market & Target firm \\
\hline Companies & 126.192 & 1 \\
Local units with resale revenue & 130.371 & 41 \\
Operational staff & 772.502 & 3.184 \\
Operating income $(\mathrm{R} \$)$ & $63,6 \mathrm{bi}$ & $1,34 \mathrm{bi}$ \\
Market share & & $2,1 \%$ \\
& $100 \%$ & \\
\hline
\end{tabular}

Source: Marked data: IBGE - Annual Commercial Survey 2009 (2011).

Available at < www.ibge.gov.br >. Consulted in May 2012, and research data.

In December 2011, the Focal Firm was composed of a network of 38 stores, seven distribution centers and an administrative headquarters, with 3,680 registered employees, of them 3,510 active (excluding those on leave). All the stores are owned outright (no franchising), located in the states of São Paulo, Minas Gerais and Paraná, and account for most of the employees $(2,417$ workers in December 2011).

\subsection{DATA}

The data used in this study were obtained from management reports and the information systems of 26 of the Focal Firm's stores, all of which operate under the home center model (stores that carry products aimed at the final part of construction or remodeling, like floor materials, plumbing and lighting fixtures, among others, aimed at end consumers). All the stores selected had data for a period of 24 months (January 2010 through December 2011), following the premise for operationalization used by Kacmar et al. (2006). We chose to use only data from home center stores because of the advantages of comparability, as proposed by Glebbeek and Bax (2004) and in line with the study by Ton and Huckman (2008).

We excluded recently opened stores (those in existence for less than a year in January 2010). The objective of this second filter was to compose a sample of stores in similar life cycle stages, past the initial growth phase. According to Kotler and Keller (2006), the "sales" variable (present in one of the hypotheses to be tested) is strongly related to the life cycle stage of a service, and hence can influence the results of the hypothesis testing. 
The data are organized in two parts, both in panel structure. The first contains information on the employees, such as date of birth, hiring date, sex, position, marital status, salary, hours of training, whether or not receiving a promotion or pay raise in the month, among others. This panel is unbalanced, since not all of the 3,088 individuals were present in all 24 months of observation (if this were true, there would have been 74,112 observations for each variable, when in reality there were 39,164 observations for each variable). Table 2 presents the descriptive statistics of the employees.

All the data in the first panel pertain to employees with labor contracts for indeterminate periods, with a workweek of 44 hours, six days a week with one day off. Temporary workers (existing in small numbers, mainly cashiers) and outsourced workers (restricted to non-core activities, such as security, cleaning, maintenance and lunch counter staff) are not included in the sample since they are not managed directly by the Focal Firm.

The second panel contains information on the stores: gross monthly sales, floor space of the product display area, flow of visitors and customers, number of employees, number of job-related accidents and other aspects potentially relevant to the study. Monthly data consolidated for each store, such as average employee age, average seniority with the company and per capita training hours, were transported to this second panel to form the base for the econometric tests. This panel contains 624 observations for each variable (a variable observed in 26 stores during 24 months). Table 3 contains the descriptive statistics on the stores.

Table 2 - Descriptive Statistics of Employees

\begin{tabular}{|c|c|c|c|c|}
\hline Variable & $\begin{array}{l}\text { Among } \\
\text { average } \\
\text { shops }\end{array}$ & $\begin{array}{l}\text { Standart } \\
\text { deviation }\end{array}$ & Minimun & Maximun \\
\hline Age (years) & 34,0 & 2,3 & 29,6 & 37,6 \\
\hline House of time (years) & 3,1 & 1,0 & 1,2 & 5,3 \\
\hline \multicolumn{5}{|l|}{ Gender ( $\%$ relative to the total) } \\
\hline Male & $61,6 \%$ & $6,7 \%$ & $48,3 \%$ & $71,2 \%$ \\
\hline Female & $38,4 \%$ & $6,7 \%$ & $28,8 \%$ & $51,7 \%$ \\
\hline \multicolumn{5}{|c|}{ Ocupation of shop ( $\%$ relative to the total) } \\
\hline Management / Supervision & $8,3 \%$ & $1,7 \%$ & $5,6 \%$ & $13,3 \%$ \\
\hline Sales & $47,6 \%$ & $4,8 \%$ & $37,2 \%$ & $56,2 \%$ \\
\hline Box & $16,9 \%$ & $2,3 \%$ & $12,7 \%$ & $21,0 \%$ \\
\hline SAC & $5,7 \%$ & $1,2 \%$ & $3,2 \%$ & $7,9 \%$ \\
\hline Deposit & $17,8 \%$ & $2,5 \%$ & $13,1 \%$ & $23,0 \%$ \\
\hline
\end{tabular}


Others operations

$3,7 \%$

$0,9 \%$

$2,3 \%$

$6,8 \%$

Status (\% relative to the total)

\begin{tabular}{lcrrr} 
Married / Marital & $42,1 \%$ & $9,3 \%$ & $24,7 \%$ & $61,4 \%$ \\
Single & $51,9 \%$ & $9,6 \%$ & $32,6 \%$ & $70,4 \%$ \\
Divorced & $4,6 \%$ & $2,6 \%$ & $0,2 \%$ & $11,3 \%$ \\
Widower & $0,4 \%$ & $0,9 \%$ & $0,0 \%$ & $3,6 \%$ \\
$\quad$ Uninformed & $0,9 \%$ & $1,8 \%$ & $0,0 \%$ & $8,4 \%$ \\
Salary (excluding sales) & 1.273 & 102 & 1.017 & 1.421 \\
Training hours per capta for month & 2,97 & 1,32 & 1,04 & 7,31 \\
Annual frequency salary increases per capta & 0,25 & 0,11 & 0,08 & 0,63 \\
Annual frequency promotions per Capta & 0,13 & 0,05 & 0,04 & 0,24 \\
\hline Source Reserch
\end{tabular}

Source: Research data.

Table 3 - Descriptive Statistics of the Stores

\begin{tabular}{lrrrr}
\hline Variable & Among & $\begin{array}{c}\text { Standart } \\
\text { Deviation }\end{array}$ & Minimun & Maximun \\
\hline Gross sales deflated by month (R\$) & 2.902 .670 & 1.347 .042 & 1.218 .094 & 6.379 .576 \\
Sales Area $\left(\mathrm{m}^{2}\right)$ & 4.021 & 1.305 & 2.210 & 7.900 \\
Visitors per Month & 44.952 & 16.173 & 23.651 & 90.669 \\
Customers with purchases by month & 12.141 & 5.274 & 5.791 & 25.407 \\
Officials Unit per Month & 60 & 19 & 32 & 116 \\
Dismissals of employees by month & 2,1 & 0,7 & 1,0 & 3,5 \\
General Manager time Front of Shop (months) & 13,7 & 6,8 & 3,0 & 30,9 \\
Accidents with removal by month & 0,02 & 0,03 & 0,00 & 0,08 \\
Accidents without removal by month & 0,07 & 0,06 & 0,00 & 0,25 \\
Accidents Band -Aid & 0,40 & 0,22 & 0,08 & 1,00 \\
\hline
\end{tabular}

Source: Research data.

\subsection{VARIABLES}

The variables used to test the four hypotheses of this study are demonstrated next, divided into three groups: dependent variables, independent variables and control variables.

\subsubsection{Dependent Variables}

The dependent variables for hypotheses $1 \mathrm{a}$ and $1 \mathrm{~b}$ are, respectively:

Sales per employee (SPE): This variable is the gross monthly sales revenue of each store divided by the number of active employees at the end of each month. In this variable, the sales are deflated according to the National Consumer Price Index (IPCA), which is measured by the IBGE, to assure the consistency of the data over the entire period. The SPE variable equalizes the productivity results among the stores. This variable was also used in the works 
of Glebbeek and Bax (2004), Shaw et al. (2005), Kacmar et al. (2006) and Siebert and Zubanov (2009).

Workplace accident frequency (WAF): This is the monthly number of work-related accidents, multiplied by one million man-hours exposed to risk, divided by the sum of the man-hours worked in the month in each store (regular and overtime). We used the definition of labor accident of the Brazilian Association of Technical Standards (ABNT, 2001), as "an unforeseen and undesirable occurrence, instantaneous or not, related to the exercise of work, that results or can result in personal injury" (ABNT, 2001). The definition is widely used by other companies in the sector in Brazil. This variable permits comparing the results of the different stores. We point out that unlike absenteeism, as suggested by Glebbeek and Bax (2004), this variable better captures the sensitivity of the Focal Firm with regard to turnover of employees.

We decomposed this variable into three parts, as follows: (a) frequency of accidents causing leave time (WAF1), with leave time defined as missing work for more than 24 hours (three days); (b) frequency of accidents with or without leave (WAF2), meaning all accidents requiring medical assistance, whether or not resulting in missed work time; and (c) frequency of registered accidents (WAF3), defined as all accidents, including minor ones only requiring first aid, usually provided at a nearby first aid post or at the store.

Hypotheses $2 \mathrm{a}$ and $2 \mathrm{~b}$ have a common dependent variable, namely:

Monthly employee turnover rate (MTO): This is the number of employees leaving (due to dismissal or resignation) in each month, divided by the number or employees of each store at the end of the month. This turnover metric was applied by Arthur (1994), Batt (2002), Glebbeek and Bax (2004) and Shaw et al. (2005).

\subsubsection{Independent Variables}

Employee turnover rate (TO): This is the independent variable for hypotheses 1a and 1b. Considering that in these two hypotheses the aim is to test the relationship between turnover and sales and between turnover and workplace accidents, relying on the monthly turnover rate could lead to errors of interpretation in situations when an employee left the company in the last few days of the month. In this case, the severance would have little effect on the dependent variables. The relevant aspect of this variable is to verify whether the degree of renewal of the team influences the store's results. Hence, we use the employee turnover in the past 12 months, or the annual turnover rate (ATO). It is calculated by adding the number 
of severances in the month of observation and in the 11 preceding months and dividing the result by the average number of employees in the period analyzed - as operationalized by Ton and Huckman (2008).

Professional recognition rate (PRR): This is the independent variable of interest for hypothesis $2 \mathrm{a}$. It is calculated by the number of pay increases and promotions in each month divided by the number of active employees at the end of each month. This variable measures the frequency of application of financial and professional recognition instruments in terms of career. The rate does not consider the percentage of pay raise. However, the internal policy of the Focal Firm establishes that salary increases are limited to $20 \%$ and are only applicable at three-month intervals. The approval of a pay raise or promotion depends on the general manager of the store, the regional operational manager, the central Human Resources Department and the Operations Division. Arthur (1994), Batt (2002) and Shaw et al. (2009) also used variables involving wages in their studies, although the formulation was different than ours.

Training investment rate (TIR): This is the independent variable of interest for hypothesis $2 b$. It is measured by the number of monthly hours spent on training employees divided by the number of active employees at the end of each month. The variable encompasses various training programs of the Focal Firm, from those required by law (such as fire brigade training and orientation of the participants of the Internal Accident Prevention Committee,), to technical and behavioral training (such as that related to specific products or selling techniques). The Focal Firm has a division within its Human Resources Department focused exclusively on training, with responsibility for validating the content, operating courses and preparing the annual training schedule. The store managers decide which employees will receive training. Once again, Arthur (1994), Batt (2002) and Shaw et al. (2009) can be cited as authors who included a training variable in their studies similar to that formulated here.

\subsubsection{Control Variables}

Store sales area (SSA): This is the available floor space for display of products, in square meters. The larger the sales area is, the more products can be displayed to customers, consequently increasing the chance of making sales (SIEBERT; ZUBANOV, 2009). In the particular case of construction materials, since the purchase is both technical and esthetic, it is hard to make a sale without giving the shopper a chance to see and touch the product. In 
relation to workplace accidents, a larger sales area means more movement of products and people, increasing the risk of accidents, justifying the use of this variable as a control.

Sales seasonality (SSN): This is a measure of the seasonal variation of sales during the year. In the construction materials segment, sales are typically highest in the period from June to November. This variable is a dummy, to capture the effects of this greater demand. Sales seasonality is also an important control variable for accidents because increased sales mean more intense operations in the stores with an increased flow of shoppers, which can diminish the employees' attention to safe practices. Although this variable is not included as a control in any of the references cited, Kacmar et al. (2006) and Siebert and Zubanov (2009) mention it, deciding to work with annualized data to eliminate the effect of seasonal variation on the data.

Average time with company (TWC): This reflects the experience of the employees. It is calculated by the sum of the length of service of active employees at the end of each month, measured in years, divided by the number of active employees at the end of the month. Considering the large range of products (some 50 thousand items) and the behavior requirements related to workplace safety, the time with the company is an important control variable, because employees need time to assimilate information on the rules, procedures and products. This control variable was also used by Siebert and Zubanov (2009).

Average employee age (AEA): This is the average age of the active employees at the end of each month. This control is relevant because selling construction materials requires a good knowledge of construction/refurbishment techniques and products, which takes time to acquire. In other words, experience is a relevant factor to promote sales, not only because of better knowledge of products and their uses, but also due to better selling skills. From the standpoint of work safety, this control is important because young people tend to act more impulsively, mainly when under pressure, making them more likely to ignore safety rules and procedures. Siebert and Zubanov (2009) also used this as a control variable.

Married employee rate (MER): Since married employees generally have greater family responsibilities than single ones, it is possible that married people are less likely to quit their jobs, and also that the company might be more reluctant to dismiss married employees due to social aspects. This rate is calculated by the ratio between married employees and the total number of employees at the end of each month. Batt (2002) used a similar control metric by including a variable to capture the percentage of women in the organizations she studied. 
Average employee salary (AES): This is the average remuneration of the employees at the end of each month, deflated by the IPCA, as done for the variable "sales per employee". Because retailing is a segment whose aggregation of value rests in the availability of the resale services offered, it has smaller contribution margins than industry. This fact implies the need to carefully administer personnel expenses, especially salaries. In the Focal Firm, payroll represents about $50 \%$ of the manageable store expenses (an example of non-manageable expense at the store level is the cost of the goods sold, since this is under the responsibility of the central procurement area). Therefore, although the salaries offered are in line with the retail market, there is competition with other markets. It is likely that stores with higher average salaries will be better able to retain their staff, justifying the inclusion of this variable as a control.

General manager time at store (MTS): This is the time, in months, that the head store manager has been in his or her current position at the end of each month. As the person in charge of a business unit, the general manager needs to present consistently good results to continue holding the position. The managers who regularly meet their targets manage to do so by engagement of their teams, since the store operation depends on them (sales, shelf stocking, after-sales services, receiving and delivery of goods, etc.). A manager with more time at the store tends to better retain employees. Shaw et al. (2009) did not specifically include a variable on the seniority of managers in leading units or teams, but one of their controls was the person who decides on the selection process, indicating the relevance of choice of employees on turnover. In the Focal Firm this responsibility rests with each store's general manager. The more experience this person has at the store, the better should be the choice of employees and the results obtained, including retention of staff.

\subsection{ESTIMATION METHODS}

We tested the hypotheses by regression of the dependent variables against the independent variables of interest and the control variables. As explained before, the data are organized in a panel structure (data from 26 stores gathered during 24 months). This data organization does not allow assuming that the observations are identically distributed over time. Consequently, unobservable factors that affect the stores may have affected them differently over time (e.g., the ability of local managers to handle staff and the business, or the quality of the store location). This implies the need to evaluate some econometric techniques for calculating the estimators of the regression. These are the ordinary least squares method 
(or weighted if there is heteroscedasticity), the fixed effects estimation method and random effects estimation method.

According to Wooldrige (2002), the definition of the best method is done by comparing the goodness of fit of the regression by the least squares method (which treats all error terms as a single one) with the quality of the fit by the random effects method. If the fit by the least squares method is better, it is the best of the three methods. However, if estimation by least squares is rejected, the Hausman test should be applied to decide between the random and fixed effects methods.

Considering the possible existence of factors related to the stores that are not directly measurable and that are not observed in the independent variables, it is important to include an error term in the equation that captures these factors, if they exist, to guarantee the consistency of the results of the estimation. Therefore, the general equation proposed is:

\section{Dependet Variable $i t=$ Coefficients of the Independent Variables $x$ Independent Variablesit + Specific Error Shopi + Residual Error $i$}

The index $i$ represents each of the stores and the index $t$ is assigned to each month of observation. Therefore, $i$ varies from 1 to 26 while $t$ ranges from January 2010 to December 2011. The specific error term only has the index $i$ because this factor does not vary with time.

\section{DISCUSSION OF THE RESULTS}

We present the results of the econometric tests according to the hypotheses formulated. For each hypothesis, we present the basic descriptive statistics of the variables used in the models, the analysis of their correlation and the coefficients calculated for each variable and its respective level of significance.

Table 4 presents the means, standard deviations and correlation coefficients of the variables in the model to test hypothesis Hla: The higher employee turnover is, the lower will be the store's sales. It can be noted that the correlation between the variable of interest annual turnover rate (ATO) and the dependent variable sales per employee (SPE) has the expected sign, negative. The control variables store sales area (SSA), sales seasonality (SSN), average time with company (TWC) and average employee age (AEA) also have the expected positive correlations with the dependent variable, sales per employee.

Table 5 reports the results of the regressions of the model to test hypothesis H1a. According to the proposed method, we calculated the regression estimators using the 
weighted least squares and random effects techniques. The regression's goodness of fit by the weighted least squares method was better, since the coefficients obtained had greater statistical significance. Therefore, it was not necessary to estimate the regression by fixed effects.

Table 4 - Means, Standard Deviations and Correlation Analysis of Variables of Model H1a

\begin{tabular}{|c|c|c|c|c|c|c|c|c|}
\hline \multirow{2}{*}{ Variable } & \multirow{2}{*}{ Among } & \multirow{2}{*}{$\begin{array}{l}\text { Standart } \\
\text { Deviation }\end{array}$} & \multicolumn{6}{|c|}{ Correlation } \\
\hline & & & 1. & 2. & 3. & 4. & 5. & 6. \\
\hline 1. VPF & 47.263 & 17.602 & 1,00 & & & & & \\
\hline 2. TOA & 0,44 & 0,20 & $-0,25$ & 1,00 & & & & \\
\hline 3. 1_ASV & 8,25 & 0,31 & 0,20 & $-0,23$ & 1,00 & & & \\
\hline 4. SZN & 0,50 & 0,50 & 0,14 & $-0,03$ & 0,00 & 1,00 & & \\
\hline 5. TMC & 2,91 & 0,99 & 0,31 & $-0,57$ & 0,25 & 0,02 & 1,00 & \\
\hline 6. IMF & 33,45 & 2,35 & 0,14 & $-0,38$ & 0,41 & $-0,01$ & 0,61 & 1,00 \\
\hline
\end{tabular}

Source: Research data.

The results of the regression indicate that the variable of interest annual turnover rate (ATO), besides being statistically significant, has a large coefficient $(-6,115.44)$, demonstrating the impact on sales per employee (SPE) if the annual turnover rate (ATO) of the Focal Firm were equal to $100 \%$. Therefore, each additional percentage point of annual turnover rate (ATO) represents $\mathrm{R} \$ 61.15$ less in sales per employee (SPE) per month. Since the average number of employees in each of the 26 stores store is 60 , each percentage point increase in annual turnover rate (ATO) represents a reduction of R $1,144,810$ in gross annual sales of the Focal Firm. Since the average annual turnover rate (ATO) is $44 \%$, it can be concluded that the impact of turnover on the Focal Firm's sales is $\mathrm{R} \$ 50.371$ million per year, all else being equal. 
Table 5 - Regression Analysis Results - Model H1a (Dependent Variable = SPE)

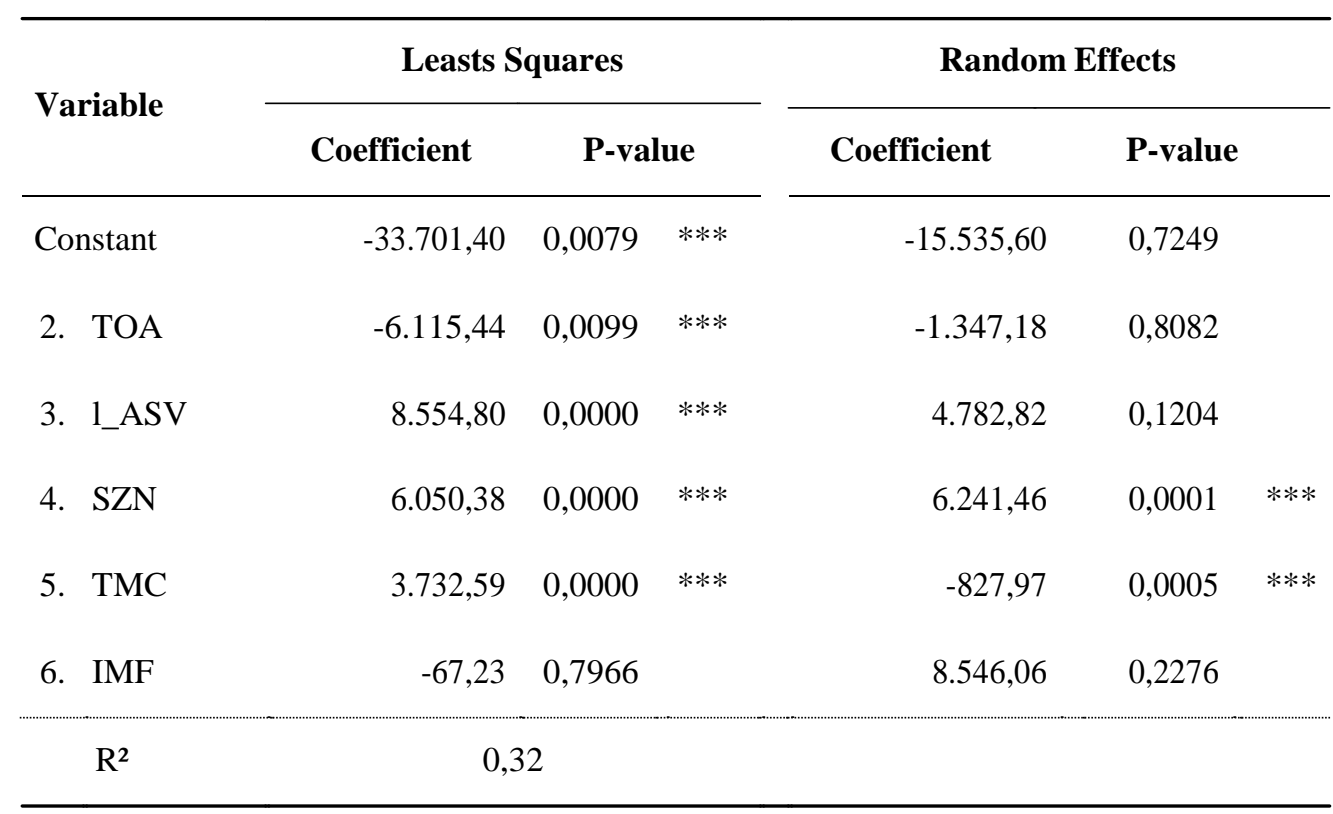

Note: $* * * p<0.01 ; * * p<0.05 ; * p<0.10$

Source: Research data.

Based on Table 6, which presents the confidence intervals of the model's coefficients, it can be stated with $95 \%$ confidence that monthly sales per employee (SPE) is at least R $\$ 14.71$ lower for each percentage point increase in the annual turnover rate (ATO), possibly reaching a reduction of $\mathrm{R} \$ 107.60$. Therefore, again considering an average of 60 employees in each of the 26 stores, and the 44\% annual turnover rate (ATO), the impact of turnover on the Focal Firm's sales results is at least R $\$ 12.119$ million per year (about $1.35 \%$ of its annual gross revenue), and can reach $\mathrm{R} \$ 88.623$ million per year (approximately $9.8 \%$ of the yearly gross revenue).

With respect to the control variables, only average employee age (AEA) was not statistically significant. It is possible that the small difference in average employee age among the stores (the standard deviation was only 2.35 years) meant that this did not contribute explanatory power to the model. All the other variables, besides being statistically significant, had high coefficients: Average time with the company (TWC), 3,732.59; sales seasonality (SSN), 6,050.38; and log of store sales area (1_SSA), 8,554.80. 
Table 6 - Confidence Interval for the Coefficients of Model H1a

\begin{tabular}{lrrr}
\hline & & \multicolumn{2}{c}{ Confidence interval (95\%) } \\
\cline { 3 - 4 } Variable & Coefficient & Lower limit & \multicolumn{1}{c}{ Upper limit } \\
\cline { 3 - 4 } Constant & $-33.701,40$ & $-58.535,70$ & $-8.867,14$ \\
2. TOA & $-6.115,44$ & $-10.759,50$ & $-1.471,38$ \\
3. 1_ASV & $8.554,80$ & $5.682,79$ & $11.426,80$ \\
4. SZN & $6.050,38$ & $4.469,37$ & $7.631,38$ \\
5. TMC & $3.732,59$ & $2.523,91$ & $4.941,27$ \\
6. IMF & $-67,23$ & $-579,30$ & 444,84 \\
\hline Source: Rese & & & \\
\hline
\end{tabular}

Source: Research data.

Table 7 presents the means, standard deviations and correlation coefficients of the variables used to test hypothesis H1b: The higher employee turnover is, the higher the store's workplace accident indices will be. It can be noted that the correlations between the variable of interest annual turnover rate (ATO) and the dependent variables workplace accident frequency with missed work (WAF1), workplace accident frequency with and without missed work (WAF2) and registered workplace accident frequency (WAF3) have the expected positive sign only with the variables workplace accident frequency with and without missed work (WAF2) and registered workplace accident frequency (WAF3).

Table 7 - Means, Standard Deviations and Correlation Analysis of the Variables of Model H1b

\begin{tabular}{|c|c|c|c|c|c|c|c|c|c|c|}
\hline \multirow{2}{*}{ Variable } & \multirow{2}{*}{ Among } & \multirow{2}{*}{$\begin{array}{l}\text { Standart } \\
\text { Deviation }\end{array}$} & \multicolumn{8}{|c|}{ Correlation } \\
\hline & & & 1. & 2. & 3. & 4. & 5. & 6. & 7. & 8. \\
\hline 1. $\mathrm{TF} 1$ & 1,92 & 13,61 & 1,00 & & & & & & & \\
\hline 2. $\mathrm{TF} 2$ & 8,45 & 30,16 & 0,45 & 1,00 & & & & & & \\
\hline 3. TF3 & 49,27 & 83,77 & 0,19 & 0,44 & 1,00 & & & & & \\
\hline 4. TOA & 0,44 & 0,20 & $-0,02$ & 0,02 & 0,20 & 1,00 & & & & \\
\hline 5. 1_ASV & 8,25 & 0,31 & 0,05 & 0,00 & $-0,04$ & $-0,23$ & 1,00 & & & \\
\hline 6. SZN & 0,50 & 0,50 & $-0,05$ & $-0,01$ & 0,00 & $-0,03$ & 0,00 & 1,00 & & \\
\hline 7. TMC & 2,91 & 0,99 & 0,04 & $-0,02$ & $-0,15$ & $-0,57$ & 0,25 & 0,02 & 1,00 & \\
\hline 8. IMF & 33,45 & 2,35 & $-0,01$ & $-0,04$ & $-0,07$ & $-0,38$ & 0,41 & $-0,01$ & 0,61 & 1,00 \\
\hline
\end{tabular}

Source: Research data. 
Despite the negative sign of the correlation between annual turnover rate (ATO) and workplace accident frequency with missed work (WAF1), this correlation is practically nil. The same observation applies to workplace accident frequency with and without missed work (WAF2), which despite having the expected positive sign in relation to annual turnover rate (ATO), has a very weak correlation. The low correlation between these variables might be due to the relatively small number of workplace accidents. In the 24 months studied there were only 14 accidents with missed work and 42 without missed work at the 26 stores. The control variables also have correlations near zero with most of the dependent variables. The only exceptions are in the relations between annual turnover rate (ATO) and registered workplace accident frequency (WAF3), with positive correlation of 0.20 , and average time with company (TWC) and registered workplace accident frequency (WAF3), with negative correlation of 0.15 .

In line with the proposed methodology, we calculated the regressions using the weighted least squares, fixed effects and random effects methods. The fixed effects calculation was necessary because the least squares estimation did not have the desired quality (only two of the variables were statistically significant in all the estimations). None of the techniques produced statistical evidence to support the proposed model, despite its good theoretical foundation.

In any event, when calculating the estimators of the regression with the dependent variable registered workplace accident frequency (WAF3), we found a significant coefficient at $1 \%$ for the variable annual turnover rate (ATO), which does not totally rule out the possibility of a relationship between turnover and workplace accidents. It is possible that application of another model would lead to stronger explanatory power of accidents. The results of the regressions to test hypothesis $\mathrm{H} 1 \mathrm{~b}$ are reported in Table 8.

Table 9 presents the means, standard deviations and correlation coefficients of the variables employed to test hypothesis $H 2 a$ : The greater the frequency of promotions and pay increases, the lower the store's employee turnover will be. It can be seen that the independent variable professional recognition rate (PRR) did not show the expected negative correlation with the dependent variable monthly employee turnover rate (MTO). In turn, the control variables had negative correlations, as suggested by the theoretical foundation underpinning the choice of variables. The only exception was the control variable general manager time at store (MTS), which had a correlation of zero with the dependent variable monthly employee turnover rate (MTO). 
Table 8 - Regression Analysis Results - Model H1b (Dependent Variable = WAF)

\begin{tabular}{|c|c|c|c|c|c|c|c|c|c|c|}
\hline \multirow{3}{*}{$\begin{array}{l}\text { Dependent } \\
\text { Variables } \\
\text { TF1 }\end{array}$} & \multirow{3}{*}{$\begin{array}{l}\text { Independent } \\
\text { Variables } \\
\text { Constant }\end{array}$} & \multicolumn{3}{|c|}{ Square minimun } & \multicolumn{3}{|c|}{ Random Effects } & \multicolumn{3}{|c|}{ Fixed Effects } \\
\hline & & \multirow{2}{*}{$\begin{array}{l}\text { Coef. } \\
-0,43\end{array}$} & \multicolumn{2}{|l|}{ P-value } & \multirow{2}{*}{$\begin{array}{l}\text { Coef. } \\
-7,50\end{array}$} & \multicolumn{2}{|l|}{ P-value } & \multirow{2}{*}{$\begin{array}{l}\text { Coef. } \\
-14,07\end{array}$} & \multicolumn{2}{|l|}{ P-value } \\
\hline & & & 0,7598 & & & 0,6342 & & & 0,6230 & \\
\hline & 4. TOA & 0,06 & 0,8091 & & 0,88 & 0,7980 & & 3,20 & 0,5777 & \\
\hline & 5. 1_ASV & 0,13 & 0,5550 & & 2,64 & 0,1733 & & & & \\
\hline & 6. SZN & $-0,02$ & 0,8690 & & $-1,49$ & 0,1712 & & $-1,46$ & 0,1868 & \\
\hline & 7. $\mathrm{TMC}$ & 0,06 & 0,5284 & & 1,16 & 0,1392 & & 1,75 & 0,5228 & \\
\hline & 8. IMF & $-0,02$ & 0,5517 & & $-0,46$ & 0,1387 & & 0,31 & 0,7354 & \\
\hline & $\mathrm{R}^{2}$ & & & 0,00 & & & & & & 0,04 \\
\hline \multirow[t]{7}{*}{ TF2 } & Constant & 5,06 & 0,8225 & & 14,30 & 0,6983 & & $-42,61$ & 0,4989 & \\
\hline & 4. TOA & 1,63 & 0,7084 & & 2,05 & 0,7942 & & $-13,02$ & 0,3031 & \\
\hline & 5. 1_ASV & 3,80 & 0,1376 & & 2,08 & 0,6465 & & & & \\
\hline & 6. $\mathrm{SZN}$ & $-0,35$ & 0,7418 & & $-0,59$ & 0,8078 & & $-0,75$ & 0,7571 & \\
\hline & 7. TMC & 0,94 & 0,3396 & & 0,71 & 0,6972 & & 1,87 & 0,7564 & \\
\hline & 8. IMF & $-1,07$ & 0,0041 & $* * *$ & $-0,77$ & 0,2876 & & 1,55 & 0,4366 & \\
\hline & $\mathrm{R}^{2}$ & & & 0,02 & & & & & & 0,05 \\
\hline \multirow[t]{7}{*}{ TF3 } & Constant & $11,75^{-}$ & 0,8791 & & $10,01^{-}$ & 0,9438 & & $-249,23$ & 0,1380 & \\
\hline & 4. TOA & 59,39 & 0,0017 & $* * *$ & 61,41 & 0,0165 & $* *$ & 36,82 & 0,2746 & \\
\hline & 5. 1_ASV & 11,47 & 0,2121 & & $-1,57$ & 0,9289 & & & & \\
\hline & 6. SZN & $-2,55$ & 0,5824 & & 0,61 & 0,9244 & & 0,27 & 0,9667 & \\
\hline & 7. TMC & $-1,56$ & 0,6466 & & $-7,19$ & 0,2799 & & $-0,70$ & 0,9651 & \\
\hline & 8. IMF & $-1,94$ & 0,1266 & & 1,96 & 0,4560 & & 8,49 & 0,1093 & \\
\hline & $\mathrm{R}^{2}$ & & & 0,05 & & & & & & 0,12 \\
\hline
\end{tabular}

Note: $* * * p<0.01 ; * * p<0.05 ; * p<0.10$

Source: Research data. 
Table 9 - Means, Standard Deviations and Correlation Analysis of the Variables of Model H2a

\begin{tabular}{|c|c|c|c|c|c|c|c|c|}
\hline \multirow{2}{*}{ Variable } & \multirow{2}{*}{ Among } & \multirow{2}{*}{$\begin{array}{l}\text { Standart } \\
\text { Deviation }\end{array}$} & \multicolumn{6}{|c|}{ Correlation } \\
\hline & & & 1. & 2. & 3. & 4. & 5. & 6. \\
\hline 1. TOM & 0,04 & 0,03 & 1,00 & & & & & \\
\hline 2. TRP & 0,02 & 0,03 & 0,13 & 1,00 & & & & \\
\hline 3. IMF & 33,45 & 2,35 & $-0,17$ & $-0,21$ & 1,00 & & & \\
\hline 4. $\mathrm{TFC}$ & 0,43 & 0,11 & $-0,20$ & $-0,20$ & 0,66 & 1,00 & & \\
\hline 5. 1_SMF & 7,09 & 0,10 & $-0,07$ & $-0,16$ & 0,29 & 0,48 & 1,00 & \\
\hline 6. $\mathrm{TGG}$ & 13,68 & 9,38 & 0,00 & $-0,05$ & $-0,19$ & 0,14 & 0,36 & 1,00 \\
\hline
\end{tabular}

Source: Research data.

As can be seen in Table 10, we did not find any significant evidence to sustain the proposed model $(\mathrm{H} 2 \mathrm{a})$. In any event, it is worth observing that the variable of interest professional recognition rate (PRR) was significant at $10 \%$. Its coefficient, however, was positive (not expected by the hypothesis formulated), with a significant value $(0.0848)$, when compared to the correlation with monthly employee turnover rate (MTO), which was 0.04 . These results might be a reflection that the recognition actions are due to turnover rather than put into practice to contain it. In other words, the main motivation of the Focal Firm in giving pay raises and promotions might be to fill spots left by people who leave the company rather than to reward the employees.

With respect to the control variables, the only one that was statistically significant, at $1 \%$, was married employee rate (MER), suggesting that greater participation of married employees reduces the monthly turnover rate. 
Table 10 - Regression Analysis Results - Model H2a (Dependent Variable = MTO)

\begin{tabular}{|c|c|c|c|c|}
\hline \multirow{2}{*}{ Variable } & \multicolumn{2}{|c|}{ Square Minimun } & \multicolumn{2}{|c|}{ Random Effects } \\
\hline & Coefficient & P-value & Coefficient & P-value \\
\hline Constant & $-0,0402$ & 0,7064 & $-0,0490$ & 0,7305 \\
\hline 2. TRP & 0,0848 & 0,0596 & 0,0870 & 0,0725 \\
\hline 3. IMF & $-0,0006$ & 0,3990 & $-0,0007$ & 0,5555 \\
\hline 4. TFC & $-0,0450$ & $0,0071 \quad * * *$ & $-0,0339$ & 0,2122 \\
\hline 5. 1_SMF & 0,0156 & 0,3070 & 0,0176 & 0,3933 \\
\hline 6. TGG & 0,0000 & 0,7976 & $-0,0001$ & 0,7700 \\
\hline $\mathrm{R}^{2}$ & 0 , & & & \\
\hline
\end{tabular}

Note: $* * * p<0.01 ; * * p<0.05 ; * p<0.10$

Source: Research data.

Table 11 reports the means, standard deviations and correlation coefficients of the variables of the model proposed to test hypothesis $H 2 b$ : The higher the number of training hours per employee, the lower the store's employee turnover will be. Once again, the variable of interest training investment rate (TIR) did not have the expected negative correlation with the dependent variable monthly employee turnover rate (MTO), as supposed for the model.

Table 11 - Means, Standard Deviations and Correlation Analysis of the Variables of Model H2b

\begin{tabular}{|c|c|c|c|c|c|c|c|c|}
\hline \multirow{2}{*}{ Variable } & \multirow{2}{*}{ Among } & \multirow{2}{*}{$\begin{array}{l}\text { Standart } \\
\text { Deviation }\end{array}$} & \multicolumn{6}{|c|}{ Correlation } \\
\hline & & & 1. & 2. & 3. & 4. & 5. & 6. \\
\hline 1. TOM & 0,04 & 0,03 & 1,00 & & & & & \\
\hline 2. TIT & 3,25 & 3,60 & 0,13 & 1,00 & & & & \\
\hline 3. IMF & 33,45 & 2,35 & $-0,17$ & $-0,13$ & 1,00 & & & \\
\hline 4. $\mathrm{TFC}$ & 0,43 & 0,11 & $-0,20$ & $-0,06$ & 0,66 & 1,00 & & \\
\hline 5. 1_SMF & 7,09 & 0,10 & $-0,07$ & 0,07 & 0,29 & 0,48 & 1,00 & \\
\hline 6. TGG & 13,68 & 9,38 & 0,00 & 0,16 & $-0,19$ & 0,14 & 0,36 & 1,00 \\
\hline
\end{tabular}

Source: Research data.

Again we used the weighted least squares, fixed effects and random effects techniques to calculate the estimators of the regression. We did not find statistical evidence to support the proposed model. However, the variable of interest training investment rate (TIR) was 
statistically significant (at 1\%) and had a positive coefficient. This result suggests that the more the company invests in training its employees, the higher will be its monthly employee turnover rate (MTO). Consequently, it is possible to suppose that the Focal Firm has difficulty in retaining qualified employees, posing important obstacles to raising the quality of its proposal for value and services.

Also in this model, the control variable married employee rate (MER) was statistically significant, at $1 \%$, supporting the assumption that married employees are more stable in their jobs. Table 12 consolidates the results obtained.

Table 12 - Regression Analysis Results - Model H2b (Dependent Variable = MTO)

\begin{tabular}{|c|c|c|c|c|c|c|}
\hline \multirow{2}{*}{ Variable } & \multicolumn{3}{|c|}{ Squares Minimun } & \multicolumn{3}{|c|}{ Random Effects } \\
\hline & Coefficient & \multicolumn{2}{|c|}{ P-value } & Coefficient & \multicolumn{2}{|c|}{ P-value } \\
\hline Constant & $-0,0076$ & 0,9425 & & $-0,0467$ & 0,7457 & \\
\hline 2. TIT & 0,0012 & 0,0006 & $* * *$ & 0,0010 & 0,0115 & $* *$ \\
\hline 3. IMF & $-0,0005$ & 0,4051 & & $-0,0006$ & 0,6326 & \\
\hline 4. $\mathrm{TFC}$ & $-0,0457$ & 0,0056 & $* * *$ & $-0,0345$ & 0,2182 & \\
\hline 5. 1_SMF & 0,0109 & 0,4760 & & 0,0167 & 0,4236 & \\
\hline 6. TGG & $-0,0001$ & 0,3779 & & $-0,0001$ & 0,5227 & \\
\hline $\mathrm{R}^{2}$ & \multicolumn{3}{|c|}{0,05} & & & \\
\hline
\end{tabular}

Note: $* * * p<0.01 ; * * p<0.05 ; * p<0.10$

Source: Research data.

Therefore, the main empirical results obtained from this study indicate that: (a) there is a strongly negative relation between employee turnover and sales of the Focal Firm, confirming Hypothesis 1a and corroborating previous studies on the subject; (b) the tests suggest that turnover is positively related with workplace accidents suffered by the Focal Firm's workers, but without statistical proof of Hypothesis 1b; (c) the data indicate that the Focal Firm's recognition actions have a positive relation with employee turnover, contrary to Hypothesis $2 \mathrm{a}$ and suggesting a possible reflection of the real motivation for those practices, which is not to reward employees; and (d) the tests indicate a positive relation between training investment and turnover, contrary to Hypothesis $2 b$ and suggesting that the Focal Firm has difficulties in retaining its qualified employees. 
Overall, the results of the tests presented in this work confirm important characteristics of other studies that have investigated the relationship between employee turnover and business performance. Although the results clearly indicate a negative effect of turnover on financial performance, it is not clear what mechanisms best explain this effect. While on the one hand the results point to a positive relation, although weak, between turnover and workplace accidents, on the other hand the relation between turnover and human resources practices seems to suggest a need for alignment of the human resources practices and the strategic objectives of company. A reactive management style that is not oriented to sustainability of the business can have unexpectedly negative effects, as suggested by the results of testing the second group of hypotheses.

\section{FINAL REMARKS}

The aim of this study was to contribute to previous investigations of the relationship between employee turnover and organizational results, considering the gap in the academic literature regarding the Brazilian context and the relevance of the subject for optimization of firms' performance. Our motivation emerged from conciliation of the theoretical perspective, which mainly indicates that high worker turnover tends to impair companies' results, with the situational context, which shows a trend for shorter job duration, mainly in the retail sector, despite the country's strong economic growth over the past decade.

In line with previous studies in the area, such as Glebbeek and Bax (2004), Kacmar et al. (2006) and Siebert and Zubanov (2009), we gathered data from the branches of a single company, to increase the comparability of the data, and consequently the validity of the results. We had two main objectives. The first was to check whether the stores of the Focal Firm with lower employee turnover tend to produce better results, in economic terms (sales volume) and organizational terms (workplace accidents). The second objective was to verify if certain human resources management practices reduce employee turnover, more specifically, whether recognition (quantity of promotions and pay raises) and investment in professional qualification (number of training hours) decrease turnover.

To attain these objectives, we formulated four hypotheses. Hypothesis 1a, regarding the relationship between turnover and sales, was confirmed, supporting the results obtained by Alexander et al. (1994), McElroy, Morrow and Rude (2001), Kacmar et al. (2006) and Siebert and Zubanov (2009). In other words, the results indicate that higher turnover reduces the sales of the Focal Firm's stores. This analysis was relevant, because besides confirming the negative effect of turnover on sales, it measured the intensity of this effect. According to our 
results, the impact of employee turnover on the Focal Firm's sales is at least R\$ 12.119 million per year (or about $1.35 \%$ of annual gross revenue), and can reach as high as $\mathrm{R} \$$ 88.623 million a year (some $9.8 \%$ of yearly sales revenue). This result, besides confirming those of previous studies (now for Brazil), suggests the dimension of the investment that the Focal Firm could allocate to retaining staff.

The next hypothesis, about the positive relation between turnover and workplace accident indices, was not confirmed. However, this result might have been related to imperfections in specifying the model, so it does not necessarily indicate the absence of a relationship between turnover and accidents.

The hypotheses "The greater the frequency of promotions and pay increases, the lower the store's employee turnover will be" and "The higher the number of training hours per employee, the lower the store's employee turnover will be" also were not confirmed. Again, it is possible that this result occurred due to the model's specification, since the coefficients of the variables of interest were statistically significant. However, the positive relationship between the rates of professional recognition and training investment on the one hand and employee turnover on the other was unexpected. This result can indicate difficulties of the Focal Firm's human resources management. Considering the possibility that the main reason for recognition actions is only to prevent employees from quitting, they might have low capacity to retain qualified employees (which can impair the organizational performance). This is an important result that deserves new investigations of the process of formulating and implementing human resources policies.

Therefore, by empirically suggesting that employee turnover has a negative effect on the Focal Firm's financial results, this study makes contributions both to the academic community and the company's managers. From the academic standpoint, there are few studies of the relationship between turnover and performance in the Brazilian context, while from the management perspective, this study identified and measured the impacts of employee turnover on retail sales revenue.

Besides this, by verifying that human resources practices, a priori considered to promote lower turnover, can instead accentuate it, this study identifies that the motivation and general organization of human resources practices are relevant factors to investigate employee turnover. Hence, this study contributes to the academic community by indicating the need in future research to pay closer attention to these questions in developing theories and models, and also to business administrators, especially in the human resources area, by indicating that 
the development and implementation of actions aiming to reduce turnover need to be well defined and coordinated. Although this is a contingent analysis to our study, it is worth mentioning that management of people is becoming more active and strategically aligned in organizations.

With respect to the limitations of this study, we only studied a single company in a specific sector: retail trade in construction materials. Therefore, the results cannot be generalized to other firms or sectors. Besides this, we used data on general turnover of employees, which includes severances both at the initiative of the employees and the company. Therefore, the results do not capture whether one type of employee turnover might be more harmful to the organizational results or more affected by human resources practices.

Finally, for future studies we suggest investigating the relationship between turnover and organizational performance in other segments and/or firms in Brazil. It would also be good to apply other performance variables, such as customer satisfaction. Other possibilities for new research are: segregating the turnover variable into spontaneous and forced severance; formulating other models that can increase the explanatory power of the relationship between workplace accidents and employee turnover; and applying models to test the influence of human resources practices on turnover in more detail, by including variables that capture the motivation and organization of actions. Besides this, an alternative methodological approach involving concepts of operational research could help advance knowledge of the subject, by adopting concepts of relative efficiency.

\section{REFERENCES}

ABELSON, M. A.; BAYSINGER, B. D. Optimal and dysfunctional turnover: toward an organizational level model. Academy of Management Review, v. 9, n. 2, p. 331-341, 1984.

ABNT. Associação Brasileira de Normas Técnicas. NBR 14280: cadastro de acidente do trabalho: procedimento e comunicação. 2001. Disponível em: <www.abnt.org.br〉. Acesso em: 15 jun. 2012.

ALEXANDER, J. A.; BLOOM, J. R.; NUCHOLS, B. A. Nursing turnover and hospital efficiency: an organization-level analysis. Industrial relations: a journal of economy and society, v. 33, n. 4, p. 505-520, 1994.

ARTHUR, J. B. Effects of human resource systems on manufacturing performance and turnover. Academy of Management Journal, v. 37, n. 3, p. 670-687, 1994.

BATT, R. Managing customer services: human resource practices, quit rates, and sales growth. Academy of Management Journal, v. 45, n. 3, p. 587-597, 2002. 
BATT, R.; COLVIN, A. J. An employment systems approach to turnover: human resources practices, quits, dismissals, and performance. Academy of Management Journal, v. 54, n. 4, p. 695-717, 2011.

BECKER, G. S. Human capital: A theoretical and empirical analysis, with special reference to education. 3. ed. Chicago: University of Chicago Press, 1994.

DALTON, D. R.; TODOR, W. D. Turnover turned over: an expanded and positive perspective. Academy of Management Review, v. 4, n. 2, p. 225-235, 1979.

GLEBBEEK, A. C.; BAX, E. H. Is high employee turnover really harmful? An empirical test using company records. Academy of Management Journal, v. 47, n. 2, p. 277-286, 2004.

GRANT, A. M.; PARKER, S. K. Redesigning work design theories: the rise of relational and proactive perspectives. The Academy of Management Annals, v. 3, n. 1, p. 317-375, 2009.

HAY GROUP. Estudo de remuneração club survey setor varejo. 2011.

HUSELID, M. A. The impact of human resource management practices on turnover, productivity, and corporate financial performance. Academy of Management Journal, v. 38, n. 3, p. 635-672, 1995.

IBGE. Indicadores IBGE: contas nacionais trimestrais: indicadores de volume e valores correntes: Outubro/Dezembro 2011. 2012. Disponível em: 〈www.ibge.gov.br〉. Acesso em: maio 2012.

Pesquisa anual de comércio 2009. 2011. Disponível em: <www.ibge.gov.br〉. Acesso em: maio 2012.

KACMAR, K. M. et al. Sure everyone can be replaced... but at what cost? Turnover as a predictor of unit-level performance. Academy of Management Journal, v. 49, n. 1, p. 133$144,2006$.

KELLER, K. L.; KOTLER, P. Administração de marketing. São Paulo: Atlas, 2006.

MCELROY, J. C.; MORROW, P. C.; RUDE, S. N. Turnover and organizational performance: a comparative analysis of the effects of voluntary, involuntary, and reductionin-force turnover. Journal of Applied Psychology, v. 86, n. 6, p. 1294, 2001.

MORROW, P.; MCELROY, J. Efficiency as a mediator in turnover: organizational performance relations. Human Relations, v. 60, n. 6, p. 827-849, 2007.

MTE. Movimentação contratual no mercado de trabalho formal e rotatividade no Brasil; 2010. Disponível em: <www.mte.gov.br>. Acesso em: set. 2011.

RAIS 2010: característica do emprego formal. 2011. Disponível em:

<www.mte.gov.br>. Acesso em: set. 2011.

RAIS: dados e estatísticas. Disponível em:

<http://portal.mte.gov.br/rais/estatisticas.htm>. Acesso em: maio 2012. 
PENCAVEL, J. H. Wages, specific training, and labor turnover in US manufacturing industries. International Economic Review, v. 13, n. 1, p. 53-64, 1972.

PRICE, J. L. The study of turnover. Iowa State University Press Ames, 1977.

SHAW, J. D. et al. Employee-organization exchange relationships, HRM practices, and quit rates of good and poor performers. Academy of Management Journal, v. 52, n. 5, p. 10161033, 2009.

SHAW, J. D. et al. Turnover, social capital losses, and performance. Academy of Management Journal, v. 48, n. 4, p. 594-606, 2005.

SHAW, J. D.; GUPTA, N.; DELERY, J. E. Alternative conceptualizations of the relationship between voluntary turnover and organizational performance. Academy of Management Journal, v. 48, n. 1, p. 50-68, 2005.

SIEBERT, W. S.; ZUBANOV, N. Searching for the optimal level of employee turnover: a study of a large UK retail organization. Academy of Management Journal, v. 52, n. 2, p. 294-313, 2009.

TON, Z.; HUCKMAN, R. S. Managing the impact of employee turnover on performance: The role of process conformance. Organization Science, v. 19, n. 1, p. 56-68, 2008.

WILLIAMS, C. R. Reward contingency, unemployment, and functional turnover. Human Resource Management Review, v. 9, n. 4, p. 549-576, 2000.

WOOLDRIDGE, J. M. Introdução à econometria: uma abordagem moderna. 5. ed. São Paulo: Cengage Learning, 2002. 